\title{
Copper lons Biosorption Properties of Biomass Derived from Algerian Sahara Plants
}

\author{
Abdelkrim Cheriti ${ }^{1}$, Mohamed Fouzi Talhi' ${ }^{1}$ \\ Nasser Belboukhari ${ }^{1}$ and Safia Taleb 2 \\ 1Phytochemistry \& Organic Synthesis Laboratory, University of Bechar, Bechar \\ ${ }^{2}$ Catalysis \& Materials Laboratory, University D. Liabes, Sidi Bel Abbes, \\ Algeria
}

\section{Introduction}

Biosorption of heavy metals from aqueous solutions is a relatively new technology for the treatment of industrial wastewater, which utilized naturally occurring waste materials derived from biomass. Generaly Heavy metals eliminated by biosorption are usually classified on three categories: toxic metals (such as $\mathrm{Hg}, \mathrm{Cr}, \mathrm{Pb}, \mathrm{Zn}, \mathrm{Cu}, \mathrm{Ni}, \mathrm{Cd}, \mathrm{As}, \mathrm{Co}, \mathrm{Sn}$, etc.), precious metals (such as $\mathrm{Pd}, \mathrm{Pt}, \mathrm{Ag}, \mathrm{Au}, \mathrm{Ru}$ etc.) and radionuclides (such as $\mathrm{U}, \mathrm{Th}, \mathrm{Ra}$, $\mathrm{Am}$, etc.), whose specific weight is usually more than $5.0 \mathrm{~g} / \mathrm{cm}^{3}$ [Bishop, 2002; Volesky, 1990; Wang \& Chen, 2006].

The heavy metal ions are stable and persistent environmental contaminants since they cannot be degraded and destroyed. These metal ions can be harmful to aquatic life and water contaminated by toxic metal ions remains a serious public health problem for human health. Numerous methods exist to remove heavy metals ions from aqueous solutions by chemical precipitation or by activated carbon as the most used adsorbent, nevertheless it is relatively expensive [Demirbas, 2008; Gabaldon et al, 1996].

The toxicity of heavy metals is apparent in reducing growth and development in microorganisms and plants, and seriously harming the health of animals and humans. In particular, heavy metals may disrupt the normal function of the central nervous system and cause changes in the blood content, and adversely affect the function of lungs, kidneys, liver and other organs. The long-term action of heavy metals may cause the development of cancer, allergy, dystrophy, physical and neurological degenerative processes, Alzheimer's and Parkinson's diseases. However, in small amounts, heavy metals are indispensable for many organisms, but their enhanced doses induce acute or chronic poisoning [Kvesitadze et al, 2006]

Adsorbent materials derived from Biomass can be used for the effective removal and recovery of heavy metal ions from wastewater: from algae [Farooq et al, 2010; Hamdy, 2000], fungi [Kapoor et al., 1999], bacteria [Ozturk, 2007], sea-weeds [Elangovan et al., 2008], some higher plants (Rahman et al., 2005), and agricultural wastes[Demirbas, 2008; Park et al, 2006].

Several reviews articles have been published about the use of certain cellulosic agricultural waste materials for the removal of heavy metal ions [Sud et al., 2008], the use of microbial 
and certain plants derived biomass types [Ahluwalia \& Goyal, 2007], use of Saccharomyces cerevisiae [Wang \& Chen, 2006], the adsorption capacity of low cost adsorbents derived from agricultural waste for heavy metals removal [ Febrianto et al, 2009; Kurniawan et al, 2006]. A number of other reviews are available in the literature [Davis et al., 2003; Lodiero et al., 2006; Nurchi \& Villaescusa, 2008].

The major advantages of biosorption technology are its effectiveness in reducing the concentration of heavy metal ions to very low levels and the use of inexpensive biosorbent. Among these, is a rapid, reversible, independent of physiological constraints of living cells, no aseptic conditions required, chemical or biological sludge is minimized, economical and eco-friendly technology in contrast to traditional methods used for removal of heavy metals from wastewaters [Cheriti et al, 2010; Talhi et al, 2009]. However, there are certain disadvantages as irrespective of the value of the metal, it needs to be desorbed from the material to be further re-employed, the characteristics of the biosorbents can not be biologically controlled [Farooq et al, 2010].

Wastes containing metals are directly or indirectly discharged into the environment increasingly, especially in developing countries, having brought serious environmental pollution, and threatened biolife [Bishop, 2002; Wang, 2002; Wang et al, 2006]. Algeria, with more than 34 million inhabitants, is located in a semi arid region, and is increasingly confronted with the problem of the scarcity of water. The country is characterized by irregular rainfall with a generally variable pattern of distribution and the major environmental issues include: soil erosion from overgrazing and other poor farming practices, desertification, dumping of raw sewage, petroleum refining wastes, and other industrial effluents is leading to the pollution of rivers and coastal waters.

Continuing our effort on the valorization of Algerian Sahara plants as biomaterials for the biosorption of toxic heavy metals from water, We present in this chapter a brief review on the use of the locally available Sahara medicinal plants Acacia raddiana, Anabasis aretioides, Retama raetam and Tamarix gallica as an adsorbent for removal of copper ion from aqueous solution. Effect of operating conditions like Temperature, $\mathrm{pH}$ and initial metal concentration, on copper biosorption were investigated. The relation between the phytochemical composition (Polyphenol, alkaloids, terpenoids, carbohydrates...) of the plants and the percent of adsorption for copper ion was examined. Thus, biosorption of copper ion occurs as a result of ion exchange or complex formation between metal ions and functional groups (hydroxyl, amine, carboxyl...) on the cell surface of the biomass derived from Algerian Sahara plants

\section{Characteristics and taxonomie of Sahara plants}

Algeria is a large North African country located on the Mediterranean Sea. Three-quarters of the country is part of the Sahara Desert lying beyond the broad ranges of the Atlas Mountains which parallel the coast. In Sahara, the climate is hot and dry in the summer, and cooler with average annual rainfall of $50 \mathrm{~mm}$ in the winter, although there may be years where there is no rain at all. The highest temperature ranges between 40 and $50{ }^{\circ} \mathrm{C}$, creating evaporation that far exceeds the amount that falls as rain and water is a serious constraint.

The flora of the central Sahara is very poor and estimated to include only 500 species [Le Houérou, 1990]. Vegetation is very contracted along the oued and the dayas with Acacia sp, Anastatica hyrochuntina, Astragalus gombo, Calligonum sp., Calotropis procera., Luanaea 
arborescens, Neurada procumbens, Panicum turgidum, Pistacia atlantica, Pithuranthos sp. and Tamarix sp., where there is sufficient ground water. Hammadas are covered by Anabasis aretioides, Anrthirrnum ramosissimuma, Arthrophytum schmittianum, Gymnocarpos decander, Helianthemum sp., Ononis angustissima and Pithuranthos chloranrhus. On sandy there are several plants, including Aristida acutiflora, Calligonum comosum, Ephedra alata ssp alenda, Genista saharae, Oudneya africana, Panicum turgidim, Retama raetam, Rhanterium suaveolens and Zilla spinosa. There is great seasonal diversity in the Saharan plant communities. Some evergreen perennials, such as Luanaea arborescens, Pityranthus tortuosus and Stachys aegyptiaca, may flower all year, whereas others have restricted flowering during the summer (Zygophyllum coccineum) or autumn (Haloxylon salicornicum), or other germinate in January during the wet season [Chehma, 2006; Ozenda, 1991; Quezel, 1965].

Plants used in this study ( Figure 1) are common in Sahara and used by local population in traditional pharmacopeia.

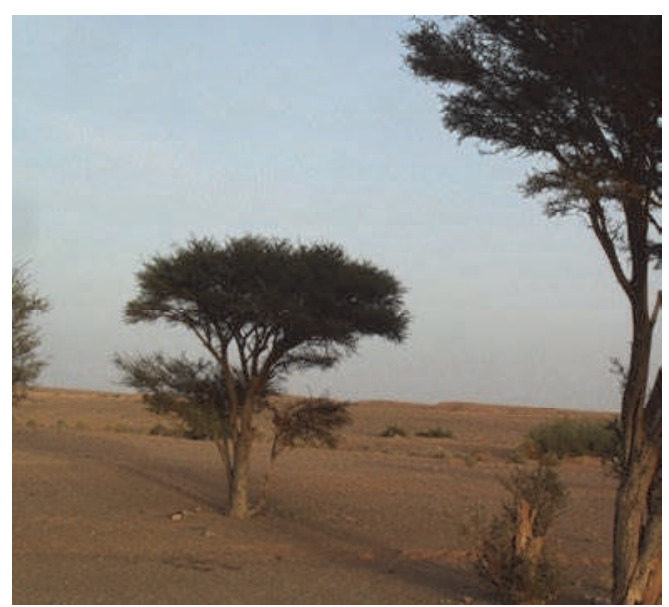

(a) Acacia raddiana (Saoura region)

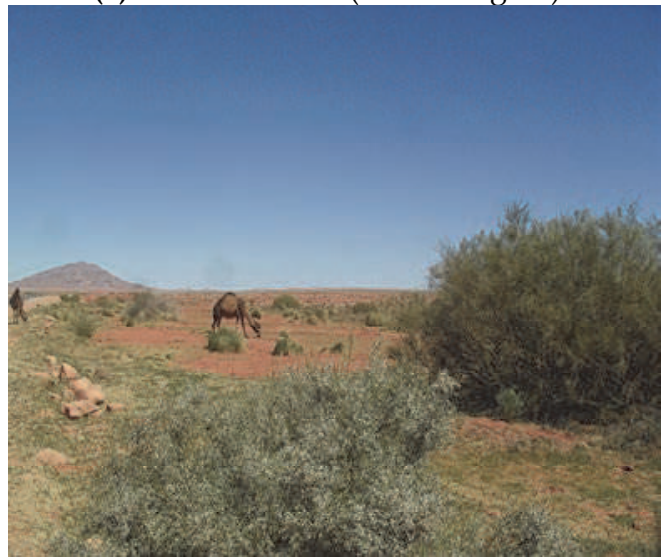

(c) Retama raetam (El Bayadh region)

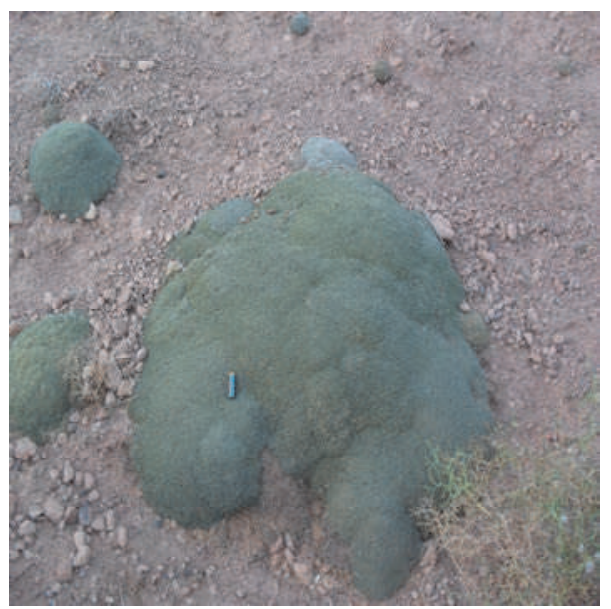

(b) Anabasis aretioides (Saoura region)

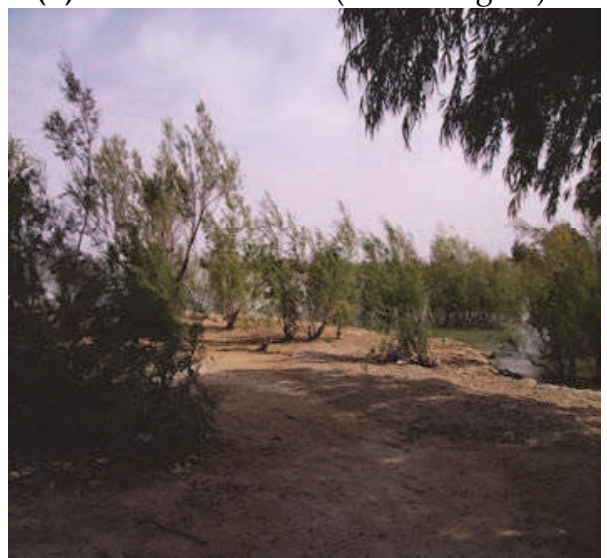

(d) Tamarix gallica (Saoura region)

Fig. 1. Saharian Plants in their natural habitat 


\subsection{Acacia raddiana savi (Vernacular name: Talh, Mimosacea family) (Fig 1 a)}

Acacia is a cosmopolitan genus containing in excess of 1350 species that together with the African and the Middle Eastern monotypic genus. In Algerian Sahara, Acacia raddiana is a medium umbrella-shaped tree 4-15 m tall, with round irregular crown and reddish bark. The flowers are arranged in heads. The legume is flattened and spirally twisted. Tree provide food and shelter for many desert animals and is a major source of livestock feed and firewood for the native people [Cheriti, 2000; Cheriti et al, 2006]. This specie is reported to tolerate annual precipitation of $10-100 \mathrm{~mm}$, arid climates with temperatures as high as $50^{\circ} \mathrm{C}$ and alkaline soils. The tree has been recommended for reclaiming dunes.

Gum from the tree is dispensed in water and used to treat ocular affections, jaundice, anthelmintic, antidiarrhoea, asthma and pulmonary diseases. Seeds, entire or powdered, are taken as antidiarrhoeic, vermifuge and dusted onto skin. Dried powdered bark used as disinfectant, for healing wounds and is a good source of tannin and used in tanning [Belakhdar, 1997; Cheriti et al, 2004; Cheriti, 2000; Ibn Baytar, 1992].

\subsection{Anabasis aretioides Coss. \& Moq. (Syn. Fredolia aretioides Coss. \& Dur., Vernacular name: Dgaa, Chenopodaceae family) (Fig 1 b)}

Anabasis aretioides is an endemic specie of South-west Algeria and South-east Morocco, grows on rocky and stony plateaux (reg and hamada). It's a vigorous cylindrical shrub, it looks like a huge cauliflower. The branches are very compact with sand in the interstices. The small fleshy leaves, not exceeding $5 \mathrm{~mm}$, are opposite, very tightly attached to the stems, and blue-green. Each leaf ends in a small spine. The long roots that creep through vertical crevices enable the plant to thrive in severe climatic conditions where the annual rainfall does not exceed $100 \mathrm{~mm}$. per year. The fruit is a small achene surrounded by transparent wings of the evergreen perianth [ Ozenda, 1991].

In local traditional medicine, $A$. aretioides is used for rheumatism, as a diuretic, as an antidote and in treatment of gynaecological disorders [Belakhdar, 1997; Cheriti et al, 2004; Cheriti, 2000].

\subsection{Retama raetam Forssk. (Vernacular name: R'tem, Fabaceae family) (Fig 1 c)}

Retama raetam Forssk is an saharo-mediterranean species; it's a glabrescent large shrub that grows to about $3 \mathrm{~m}$ on sandy soils and in dry conditions (rainfall around $100 \mathrm{~mm}$. per year), common in the Northern Africa and East Mediterranean region [Chehma, 2006; Quezel, 1965]. The leaves, which are very small (about 6-7 mm. long), simple, subsessile and narrow (only $1 \mathrm{~mm}$. wide), drop quickly and the plant remains leafless for most of the year. The flowers are 8-10 mm. long, white and pea-like, appearing close to the stem in clusters of 315. The hairless grape-shaped seed pod (10-15 mm. diameters) contains one or two kidneyshaped seeds, which are about $6.5 \mathrm{~mm}$. long and may be yellow, green, brown or black. The plant flowers from March to April and plays an important ecological role, it is widely used in dune stabilisation and soil fixation and as a good fuel wood.

In Algeria, R. raetam it is largely located in Sahara and arid steppe regions, provide food for many desert animals and is largely recommended by traditional herbal healers for treatment of various illness as diabetes, hypertension, gastro-intestinal disorders and as an antiseptic for wounds, skin rash and pruritus. Powdered branches mixed with honey are emetic, given as a purgative and vermifuge. The flowers are an important source of fodder for dromedaries [Belakhdar, 1997; Cheriti et al, 2006; Cheriti, 2000]. 


\subsection{Tamarix gallica L. (Vernacular name: L’ariche, Tamaricaceae family) (Fig $1 \mathrm{~d}$ )}

Tamarix gallica $L$. is a perennial small tree, densely ramified, abundant along streams and oued with a high salt content, rich clay soil and with a moderate sand accumulation. The purple-brown bark of this desert tree is initially smooth with numerous elongated lenticels, later developing shallow splits and becoming rough when mature. The leaves are tiny, greygreen, 1-3 mm. Flowering starts around March and lasts until May. The small flowers have 5 lavender pink or white petals $1.5-2 \mathrm{~mm}$. long, numerous on long, very slender, spike-like racemes in terminal panicles. The fruit is a small dry capsule containing small cottony seeds[Quezel, 1965]. Its wood is used in local construction, for dyeing and as fuel.

The decoction of leaves and young branches are used in Saharan traditional medicine as a vermifuge, antihaemorrhoid and in treatment of diarrhoea, rheumatism and as antialgetic for toothache and to cure dromedary galls [Belakhdar, 1997; Cheriti et al, 2006; Cheriti, 2004].

\section{Biosorption of copper ion by different biomass}

Recently, the surge of industrial activities has intensified more environmental problems as seen for example in the deterioration of several ecosystems due to the accumulation of dangerous polluants such as heavy metals [ Park et al, 2006]. The heavy metal pollution has naturally become one of the most serious environmental problems today. Due to their persistence in nature, increased susceptibility to disease in man and animal (hepatic, kidney, nerves and the immune system damage and block functional vital groups.....) and toxic characteristics of heavy metals displayed as follows: The toxicity of heavy metals occurs even in low concentration of about $1.0-10 \mathrm{mg} / \mathrm{L}$. Some strong toxic metal ions, such as $\mathrm{Hg}$ and $\mathrm{Cd}$, are very toxic even in lower concentration of $0.001-0.1 \mathrm{mg} / \mathrm{L}$; the toxicity can last for a long time in nature; some heavy metals even could be transformed from relevant low toxic species in to more toxic forms in a certain environment; the bioaccumulation by food chain could damage normal physiological activity and endanger human life; cannot be degraded by any methods including biotreatment [ Wang and Chen, 2006; Wang, 2002].

Knowledge about toxicological effects of heavy metals on the environment and in drinking water is well recognized and therefore, it is inevitable to search for different methods to reduce water pollution. Conventional methods for removing heavy metal ions from aqueous solution have been studied, such as chemical precipitation, ion exchange, electrochemical treatment, membrane technologies and adsorption. Than, Copper $(\mathrm{Cu})$ is one of the most important heavy metals often found in effluents discharged from industries and not biodegradable and travels through the food chain via bioaccumulation, which is potentially toxic. The excessive intake of copper results in its accumulation in the liver causing haemolysis, liver and kidney damage, irritation of the upper respiratory tract, chronic asthma, gastrointestinal disturbance, anemia and diarrhoea, Wilson desease and dermatitis [ Cheriti et al, 2009; Kurniawan et al, 2006]. Thus, it becomes essential to search for different methods to reduce water pollution and to remove these heavy metals from wastewaters.

Biosorption is again promoted as a potential biotechnology for removal of heavy metals and related organic substances from waste streams and effluents. A wide range of microbial biomass types have been investigated in biosorption studies, including many kinds of macroalgae (seaweeds), plant materials (leaves, bark, sawdust), animal materials (hair, crustaceans) have also been studied [ Gadd, 2009; Niua et al 2007; Zhang \& Banks, 2006]. A common rationale is that 'waste' biomass will provide an economic advantage with low costs and availability in large quantities, easily regenerable, and cheap [ Hashem, 2007]. 
Chemical modification of biomass may create derivatives with altered metal binding abilities and affinities [ Bae et al, 2000; Gadd, 2009]. Aspergillus niger mycelium was modified by introducing additional carboxy or ethyldiamino groups which increased metal biosorption [ Kramer \& Meish, 1999] ( Table 1).

\begin{tabular}{|c|c|}
\hline BioSorbent & $q_{\mathrm{m}}(\mathrm{mg} / \mathrm{g})$ \\
\hline Acacia raddiana ( Talhi et al, 2010) & 82.63 \\
\hline Apple wastes & 10.8 \\
\hline Bacillus subtilis & 146.09 \\
\hline Banana pith & 13.5 \\
\hline Cellulose & 7.06 \\
\hline Chitin & 29.04 \\
\hline Coirpith carbon & 39.7 \\
\hline Cork & 20 \\
\hline Cork bark & 2.96 \\
\hline Cottonseed hulls & 19.1 \\
\hline Dehydrated wheat bran (DWB) & 51.5 \\
\hline Ganoderma & 23.83 \\
\hline Grape stalks & 10.10 \\
\hline Lignite & 6.35 \\
\hline Mentha spicatum & 10.37 \\
\hline Oil-palm fibre & 1.98 \\
\hline Padina sp. & 50.8 \\
\hline Peanut hull carbon & 65.57 \\
\hline Penicillium ochrochloron & 80.70 \\
\hline Plant root tissues & 0.50 \\
\hline Pollen & 6.23 \\
\hline Rice bran & 33.58 \\
\hline Saccharomyces cerevisiae & 30.50 \\
\hline Saragassum fluitans & 108.03 \\
\hline Sawdust & 1.79 \\
\hline Scenedesmus obliqus & 10.04 \\
\hline Soybean hulls & 38.7 \\
\hline Sphaerotilus natans & 60 \\
\hline Sphagnum moss peat & 16.4 \\
\hline sugar beet pulp & 17.1 \\
\hline Sunflower & 89.37 \\
\hline Tree fern & 11.7 \\
\hline Washed sugar beet pulp & 21.1 \\
\hline Yohimbe bark & 9.42 \\
\hline
\end{tabular}

Table 1. Maximum capacities of copper(II) ions biosorption by various biosorbents (compiled from [ Benaissa \& Elouchdi, 2007])

Biomass used for biosorption may be living or dead. While the use of dead biomass or derived products may be easier by reducing complexity, the influence of metabolic processes on sorption is often unappreciated, particularly where there is scant biological input to the problem [Gadd, 2009]. Removal of heavy metals using agricultural waste and its 
industrial by products has been massively investigated due to the abundance of agricultural materials in nature and its low cost [ Febrianto et al, 2009].

It was noted that the $\mathrm{pH}$ value of the solution is of great importance in both cation and anion biosorption. However, the optimum $\mathrm{pH}$ for anion biosorption is opposite to that of cation biosorption. While cation biosorption is favored at increased $\mathrm{pH}>4.5$ [Kratochvil 1997], anion adsorption is preferred in a lower $\mathrm{pH}$ range of $\mathrm{pH} 1.5-4$ [Gaff, 1992]. This was determined based on the characteristics of the biomass as well as considering the speciation of metals in the solution. The $\mathrm{pH}$ value of solution strongly influences not only the site dissociation of the biomass surface, but also the solution chemistry of the heavy metals: hydrolysis, complexation by organic and/or inorganic ligands, redox reactions, precipitation, the speciation and the biosorption availability of the heavy metals [Wang, 2002].

The temperature can influence the sorption process [Naja et al. 2008] whereas temperatures of $60^{\circ} \mathrm{C}$ or more caused a change in the texture of the sorbent and a loss in the sorption capacity due to the material deterioration. Biomass usually contains more than one type of sites for metal binding. This was confirmed in $\mathrm{Cu}$ adsorption by potassium-saturated microbial biomass. For most metals, the heat of reaction was constant, independent of the degree of site occupation. For $\mathrm{Cu}$, however, the heat of reaction decreased with increasing degree of site occupation from 27 to $14 \mathrm{~kJ} / \mathrm{mol}$, indicating the involvement of different binding sites or the formation of different types of $\mathrm{Cu}$ complexes with the biomass [Naja \& Volesky, 2011; Weppen \& Hornburg, 1995].

Biosorption is rather difficult to define because many mechanisms may contribute to the overall process depending on the substance to be sorbed, the biosorbent used, environmental factors and the presence or absence of metabolic processes in the case of living organisms [Gadd, 2009].

\section{Mechanisms of biosorption}

Biosorptive capacity of heavy metals is influenced by many factors, including the status of biosorbent, properties of metal ions (radius of ion, valence, etc.) in aqueous solution, experimental conditions (such as $\mathrm{pH}$, temperature, contact time, co-ions in solution, initial concentration of metal and biomass.

Biosorption is a physico-chemical process and includes such mechanisms as absorption, adsorption, ion exchange, surface complexation and precipitation [Gadd, 2009]. A variety of mechanisms are involved in the removal of such diverse substances from solution. A cation can associate with a surface as an inner-sphere or outer-sphere complex depending whether a chemical bond is formed between the metal and the electron donating oxygen ion in this case (inner-sphere complex) or if a cation approaches the surface negative groups to a critical distance. It is necessary to distinguish between chemisorption, which involves chemical binding, and physisorption that depends strictly on the surface-based physical forces of interfacial imbalance and attraction (e.g. van der Waals). Also there is deference between active metabolically mediated metal uptake by living cells as opposed to passive metal sequestering by dead biomass. In general, biosorption can be defined as the passive sequestering of metal ions by metabolically inactive biomass and is considered to be a fast physical/chemical process [Febrianto et al, 2009; Naja \& Volesky, 2011; Wang \& Chen, 2006]. In the literature another models have been reported with different schematizations of the interfacial structure in terms of supposed reactions, description of the electric double layer 
introduction of cooperative phenomena and continuous distribution for the equilibrium constants among active sites and ionic species in solution [ Pagnanalli, 2011].

\subsection{Biosorption models}

Biosorption isotherms are used to describe the experimental adsorbed amount $\mathrm{q}_{\mathrm{e}}(\mathrm{mg} / \mathrm{g})$ as a function of the equilibrium concentration Ce $(\mathrm{mg} / \mathrm{L})$ of the adsorbing molecule at constant temperature. Than, Equilibrium isotherm models are usually classified into the empirical equations and mechanistic models, based on the mechanism of metal ion biosorption. Mechanistic models can be used not only to represent, but also to explain and predict the experimental behavior [Liu et al., 2002; Pagnanelli et al., 2002). The empirical models for single solute systems used to describe the biosorption equilibrium are Langmuir (based on monolayer adsorption of solute), Freundlich (developed for heterogeneous surfaces ), Brunauer-Emmett-Teller (BET), Skips, Henry and Temkin models. However, Langmuir and Freundlich are the most widely accepted and used in a number of references. These models can provide information of metal-uptake capacities and differences in metal uptake between various species and have been widely applied since they are simple, give a good description of experimental behaviour in a large range of fixed operating conditions, and are characterised by a limited number of adjustable parameters [Kapoor \& Viraraghavan, 1995; Pagnanelli et al., 2002]. Several biosorption isotherms originally used for gaz phase adsorption are vailable readily adopted to correlate adsorption equilibria in heavy metals biosorption.

\subsubsection{Freundlich isotherm}

Freundlich isotherm is an empirical equation (Eq. 1) most widely used for the description of adsorption equilibrium. Freundlich isotherm is capable of describing the adsorption of organic and inorganic compounds on a wide variety of adsorbents including biosorbent.

$$
\log q_{e}=\log K_{F}+\frac{1}{n} \log C_{e}
$$

Where $q_{\mathrm{e}}$ is the amount of metal ion sorbed at equilibrium per unit weight of sorbent $(\mathrm{mg} / \mathrm{g})$, $C_{\mathrm{e}}$ the equilibrium concentration of metal ion in the solution $(\mathrm{mg} / \mathrm{L})$, The Freundlich model constants $K_{\mathrm{F}}$ and $n$ indicate respectively the relative sorption capacity of the sorbent and the intensity of the sorption. The plot $\log q_{\mathrm{e}}$ versus $\log C_{\mathrm{e}}$, gives a straight line of slope, which will permit us to obtain the constants from their intercepts and slopes [ Cheriti et al, 2009].

$\log K_{\mathrm{F}}$ is equivalent to $\log$ qe when Ce equals unity. However, in other case when $1 / n \neq 1$, the $K_{F}$ value depends on the units upon which qe and $C_{\mathrm{e}}$ are expressed. On average, a favorable adsorption tends to have Freundlich constant $n$ between 1 and 10. Larger value of $n$ (smaller value of $1 / n$ ) implies stronger interaction between biosorbent and heavy metal while $1 / n$ equal to 1 indicates linear adsorption leading to identical adsorption energies for all sites [Delle Site, 2001].

Freundlich isotherm has the ability to fit nearly all experimental adsorption-desorption data, and is especially excellent for fitting data from highly heterogeneous sorbent systems but does not predict an adsorption maximum and implies that the adsorption energy of a surface varies with surface coverage [Pagnanelli, 2001]. Table 2 abridges a number of studies that draw upon Freundlich isotherm to interpret biosorption equilibrium data of Copper ions. 


\begin{tabular}{|c|c|c|c|c|c|}
\hline \multirow{2}{*}{ Biosorbent } & \multicolumn{2}{|c|}{ Operational condition } & \multicolumn{3}{|c|}{ Freundlich parameters } \\
\hline & $\mathrm{pH}$ & $\mathrm{T} \circ \mathrm{C}$ & $K_{\mathrm{F}}$ & $n$ & $R^{2}$ \\
\hline $\begin{array}{l}\text { Acacia raddiana } \\
\text { [Talhi et al, 2010] }\end{array}$ & 5.0 & 25 & 8.75 & 1.54 & 0.971 \\
\hline Aspergillus niger & - & 20 & 1.77 & 2.05 & 0.886 \\
\hline Crab shell particles & 3.5 & - & 2.05 & 1.68 & 0.979 \\
\hline Tea waste & $5-6$ & 22 & 0.70 & 1.35 & 0.984 \\
\hline Tea industry waste & 5.5 & 25 & 0.45 & 1.18 & 0.992 \\
\hline Atriplex canescens & 5.0 & $24 \pm 2$ & 4.02 & 1.04 & 0.979 \\
\hline Caulerpa lentillifera & 5.0 & - & 10.44 & 1.27 & 0.971 \\
\hline $\begin{array}{c}\text { green algae Cladophora } \\
\text { fascicularis }\end{array}$ & 5.0 & 25 & 84.38 & 2.45 & 0.998 \\
\hline Sour Orange Residue & 4.5 & 28 & 9.52 & 2.90 & 0.980 \\
\hline $\begin{array}{c}\text { Sour Orange Residue } \\
(\mathrm{NaOH} \text { treated })\end{array}$ & & & 5.52 & 3.74 & 0.980 \\
\hline \multirow[t]{3}{*}{ Brown seaweed } & 5 & 25 & 5.5 .70 & 2.30 & 0.908 \\
\hline & & 40 & 5.20 & 2.10 & 0.953 \\
\hline & & 55 & 5.40 & 2.00 & 0.917 \\
\hline \multirow[t]{3}{*}{ Litter of poplar forests } & 4.5 & 25 & 6.14 & 3.89 & 0.966 \\
\hline & & 45 & 8.32 & 3.31 & 0.875 \\
\hline & & 60 & 14.18 & 5.57 & 1.000 \\
\hline Pretreated Aspergillus niger & $5.5 \pm 0.5$ & - & 5.35 & 2.38 & 0.890 \\
\hline \multirow[t]{3}{*}{ Lentil shell } & 6 & 20 & 0.65 & 2.77 & 0.993 \\
\hline & & 40 & 1.20 & 2.58 & 0.964 \\
\hline & & 60 & 1.14 & 2.87 & 0.901 \\
\hline \multirow[t]{3}{*}{ Wheat shell } & & 20 & 0.019 & 10.91 & 0.910 \\
\hline & & 40 & 0.034 & 9.59 & 0.955 \\
\hline & & 60 & 0.022 & 13.43 & 0.945 \\
\hline \multirow[t]{3}{*}{ Rice shell } & & 20 & 0.108 & 2.79 & 0.996 \\
\hline & & 40 & 0.148 & 2.82 & 0.929 \\
\hline & & 60 & 0.130 & 3.19 & 0.938 \\
\hline Myriophyllum spicatum L & & & 1.60 & 1.20 & 0.950 \\
\hline \multirow[t]{3}{*}{ Cedar sawdust } & $5-6$ & 25 & 0.59 & 1.02 & 0.938 \\
\hline & & 35 & 1.04 & 1.13 & 0.969 \\
\hline & & 45 & 1.19 & 1.25 & 0.986 \\
\hline \multirow[t]{3}{*}{ Crushed brick } & & 25 & 0.75 & 1.19 & 0.957 \\
\hline & & 35 & 1.04 & 1.23 & 0.968 \\
\hline & & 45 & 1.54 & 1.49 & 0.964 \\
\hline PVA-Sargassum & 5 & $22 \pm 1$ & 0.19 & 7.143 & 0.83 \\
\hline Free suspended Sargassum & & & 0.56 & 3.226 & 0.95 \\
\hline Rhyzopus oryzae (viable) & $4-6$ & 21 & 8.65 & 6.67 & 0.921 \\
\hline Rhizopus oryzae (NaOH treated) & & & 11.07 & 11.07 & 0.836 \\
\hline
\end{tabular}

Table 2. Freundlich parameters and conditions for biosorption of copper ion by various biosorbents ( compiled from [Febrianto et al 2009])

Sorption of copper on any sorbent can occur either by physical bonding, ion exchange, complexation, chelation or through a combination of these interactions. In the first case of physical bonding. Miscellaneous functional groups such as hydroxyl, carbonyl, carboxyl, sulfhydryl, thioether, sulfonate, amine, imine, amide, imidazole, phosphonate, and 
phosphodiester groups, can present within the structure of biosorbent, the mechanism of adsorption will not be restricted to physical bonding [Cay et al, 2004; Febrianto et al, 2009; Popuri et al, 2007]. Different mechanisms can be involved as the interaction between sorbent and solute molecules is expected to be strong. The parameter $n$ of Freundlich equation in Table 2 expresses these phenomena.

\subsubsection{Langmuir isotherm}

The Langmuir equation (Eq. 2) was derived using the following assumptions [Pagnanelli, 2011]:

- The surface of the adsorbent has a fixed number of identical sites which can each retain one molecule, resulting in adsorption monolayer coverage.

- Reversible Adsorption process..

- Adsorption energy for all sites is identical, regardless of surface coverage

$$
\frac{C_{e}}{q_{e}}=\frac{1}{b q_{m}}+\frac{C_{e}}{q_{m}}
$$

Where $q_{\mathrm{e}}$ is the amount of metal ion sorbed at equilibrium per unit weight of sorbent $(\mathrm{mg} / \mathrm{g}), C_{\mathrm{e}}$ the equilibrium concentration of metal ion in the solution $(\mathrm{mg} / \mathrm{L}), q_{\mathrm{m}}$ and $b$ the Langmuir model constants, indicate respectively the monolayer sorption capacity and the constant related to the free energy of sorption. The plot of $C_{\mathrm{e}} / q_{e}$ versus $C e$ give a straight line of slope, which will permit us to obtain the constants from their intercepts and slopes. Example of Langmuir parameters and conditions for biosorption of copper ion by various biosorbents are tabulated in Table 3.

In biosorption process, saturation limit of certain biomass is affected by several factors such as the number of sites in the biosorbent material, the accessibility of the sites, the chemical state of the sites and the affinity between the site and the metal.

The easy interpretation of Langmuir parameters made the fortune of this model: in fact $q_{m}$ is often used to compare biosorbent performances in terms of maximum capacity, while b, which characterise the initial slope of the isotherm, is taken as a measure of the biosorbent affinity for a metal [ Pagnanelli, 2011].

Within the Langmuir model, the saturation capacity qmax is supposed to coincide with saturation of a fixed number of identical surface sites and as such, it should logically be independent of temperature. The decrease of $b$ value with temperature rise signifies the exothermicity of the adsorption process (physical adsorption) [Shaker, 2007], while the opposite trend indicates that the process needs thermal energy (endothermic), leading to chemisorption [Dundar et al, 2008; Vilar et al, 2008]. In physical adsorption, the bonding between heavy metals and active sites of the biosorbent weakens at higher temperature in contrast with chemisorption bonding which becomes stronger.

\subsection{Biosorption kinetic}

Several biosorption kinetic models have been established to understand the kinetics and rate limiting step. These include pseudo-first and second-order rate model [Febrianto et al,2009], Weber and Morris sorption kinetic model, Adam-Bohart-Thomas relation, first-order reversible reaction model, external mass transfer model, first-order equation of Bhattacharya and Venkobachar, Elovich's model and Ritchie's equation. The pseudo-first and secondorder kinetic models are the most used to study the biosorption kinetics of heavy metals and quantify the extent of uptake in biosorption kinetics. 


\begin{tabular}{|c|c|c|c|c|c|}
\hline \multirow{2}{*}{ Biosorbent } & \multicolumn{2}{|c|}{ Operational condition } & \multicolumn{3}{|c|}{ Langmuir parameters } \\
\hline & $\mathrm{pH}$ & $\mathrm{T} \circ \mathrm{C}$ & $b$ & $q_{\mathrm{m}}$ & $R^{2}$ \\
\hline Acacia raddiana [Talhi et al, 2010] & 5.0 & 25 & 0.073 & 82.63 & 0.985 \\
\hline \multirow[t]{3}{*}{ Aspergillus niger } & - & 20 & 0.0120 & 33.11 & 0.944 \\
\hline & & 25 & 0.0150 & 33.23 & 0.941 \\
\hline & & 35 & 0.0260 & 33.54 & 0.939 \\
\hline \multirow[t]{4}{*}{ Green alga Cladophora fascicularis } & 5.0 & 15 & 0.1406 & 47.019 & \\
\hline & & 25 & 0.1607 & 70.53 & \\
\hline & & 35 & 0.1649 & 92.77 & \\
\hline & & 45 & 0.1882 & 110.56 & \\
\hline Tea waste & $5-6$ & 22 & 0.0076 & 48.00 & 0.994 \\
\hline Spent grain & 4.2 & - & 0.0800 & 10.47 & 0.995 \\
\hline Pretreated Aspergillus niger & 5.5 & - & 0.1888 & 2.61 & 0.990 \\
\hline \multirow[t]{3}{*}{ Lentil shell } & 6 & 20 & 0.0190 & 8.98 & 0.980 \\
\hline & & 40 & 0.0220 & 9.51 & 0.981 \\
\hline & & 60 & 0.0410 & 9.59 & 0.999 \\
\hline \multirow[t]{3}{*}{ Wheat shell } & & 20 & 0.0020 & 7.39 & 0.925 \\
\hline & & 40 & 0.0040 & 16.08 & 0.791 \\
\hline & & 60 & 0.0050 & 17.42 & 0.883 \\
\hline \multirow[t]{3}{*}{ Rice shell } & & 20 & 0.0110 & 1.85 & 0.991 \\
\hline & & 40 & 0.0160 & 2.31 & 0.982 \\
\hline & & 60 & 0.0180 & 2.95 & 0.987 \\
\hline \multirow[t]{3}{*}{ Brown seaweed } & 5 & 25 & 0.0260 & 82.60 & 0.998 \\
\hline & & 40 & 0.0240 & 88.00 & 0.997 \\
\hline & & 55 & 0.0254 & 93.90 & 0.996 \\
\hline \multirow[t]{3}{*}{ Caulerpa lentillifera } & 5.0 & - & 0.0760 & 5.57 & 0.968 \\
\hline & 4.0 & & 0.0618 & 42.37 & 0.995 \\
\hline & 3.0 & & 0.0290 & 2.64 & 0.995 \\
\hline Atriplex canescens & 5.0 & 24 & 9.0900 & 590.92 & 0.0001 \\
\hline \multirow[t]{3}{*}{$\begin{array}{l}\text { Non-living green algae } \\
\text { Cladophora fascicularis }\end{array}$} & 5.0 & 25 & 0.0652 & 102.55 & 0.997 \\
\hline & & 35 & 0.1241 & 106.81 & 0.998 \\
\hline & & 45 & 0.1750 & 112.97 & 1.000 \\
\hline Sour orange residue & 4.5 & 28 & 0.0660 & 52.08 & 0.990 \\
\hline $\begin{array}{l}\text { Sour orange residue }(\mathrm{NaOH} \\
\text { treated) }\end{array}$ & & & 0.0540 & 23.47 & 0.980 \\
\hline \multirow[t]{2}{*}{ Litter of poplar forests } & 4.5 & 25 & $1.66 \times 10-4$ & 19.53 & 0.991 \\
\hline & & 60 & $3.574 \times 10-4$ & 29.33 & 0.972 \\
\hline Pre-treated arca shell biomass & & 25 & 0.0590 & 26.88 & 0.979 \\
\hline Myriophyllum spicatum L. & & 20 & 0.0120 & 113.00 & 0.110 \\
\hline \multirow{2}{*}{ Algal waste } & & 20 & 0.0028 & 16.7 & 0.950 \\
\hline & & 35 & 0.0053 & 17.0 & 0.950 \\
\hline \multirow[t]{2}{*}{ Cedar sawdust } & $5-6$ & 25 & $3.584 \times 10-3$ & 294.12 & 0.977 \\
\hline & & 35 & $6.290 \times 10-3$ & 144.93 & 0.977 \\
\hline Crushed brick & & 25 & $5.274 \times 10-3$ & 153.85 & 0.973 \\
\hline PVA-Sargassum & 5 & $22 \pm 1$ & 28.0700 & 0.21 & 0.960 \\
\hline Freely suspended Sargassum & & & 2.8600 & 0.96 & 0.980 \\
\hline Rhyzopus oryzae (viable) & $4-6$ & 21 & 0.1290 & 19.40 & 0.999 \\
\hline Rhyzopus oryzae (NaOH treated) & & & 0.0280 & 43.70 & 0.999 \\
\hline Lignin & 5.5 & 20 & 0.4309 & 22.87 & 0.978 \\
\hline $\begin{array}{l}\text { Non-living lichen biomass of } \\
\text { Cladonia rangiformis hoffm }\end{array}$ & & 15 & 0.1051 & 7.69 & 0.998 \\
\hline $\begin{array}{l}\text { Lignocellulosic substrate } \\
\text { (Wheat bran extract) }\end{array}$ & 4.5 & & 2.9600 & 12.58 & 0.980 \\
\hline
\end{tabular}




\begin{tabular}{|c|c|c|c|c|c|}
\hline \multirow{2}{*}{ Biosorbent } & \multicolumn{2}{|c|}{ Operational condition } & \multicolumn{3}{|c|}{ Langmuir parameters } \\
\hline & $\mathrm{pH}$ & $\mathrm{T} \circ \mathrm{C}$ & $b$ & $q_{\mathrm{m}}$ & $R^{2}$ \\
\hline Phosphorylated orange waste & 4.5 & 30 & 0.0452 & 67.35 & 0.990 \\
\hline Birch wood Betula sp. & 5.5 & 22 & 0.2000 & 4.90 & $>0.997$ \\
\hline Brown alga Fucus vesiculosus & & & 1.1000 & 23.40 & $>0.997$ \\
\hline $\begin{array}{c}\text { Terrestrial moss Pleurozium } \\
\text { schreberi }\end{array}$ & & & 1.1500 & 11.10 & $>0.997$ \\
\hline Cupriavidus taiwanensis TJ208 & 5 & 37 & 0.0363 & 19.00 & 0.887 \\
\hline $\begin{array}{c}\text { Mimosa pudica inoculated with } \\
\text { TJ208 }\end{array}$ & 5 & & 0.0990 & 25.40 & 0.966 \\
\hline Mimosa pudica without inoculation & 5 & & 0.0614 & 22.70 & 0.923 \\
\hline
\end{tabular}

Table 3. Langmuir parameters and conditions for biosorption of copper ion by various biosorbents ( compiled from[Febrianto et al 2009] )

A comprehensive reviews is available and can be referred upon by interested readers [ Febrianto et al, 2009]. In biosorption of copper ion using cedar sawdust, two control mechanisms were observed, the film diffusion process controlled the early stage of biosorption process while in the later stage, chemical reaction become the limiting mechanism. The diffusion coefficient value of copper ions was $6.31 \times 10^{-11} \mathrm{~cm}^{2} / \mathrm{s}$. Similar mechanism was also observed [Febrianto et al, 2009].

The exothermicity or endothermicity of the biosorption process can be determined via heat of adsorption. This thermodynamic property is commonly obtained through integrated Van't Hoff equation, which relates the Langmuir constant, $b$ to the temperature. Heats of adsorptions $E \mathrm{a}(\mathrm{kJ} / \mathrm{mol})$ calculated for copper-biosorbent systems: Cedar sawdust [Djeribi \& Hamdaoui, 2008], and Cladophora fascicularis [Deng et al, 2006], Shells of lentil and Shells of rice[Aydin et al, 2008] are respectively as: $-9.70,39.00,15.37$ and 18.79.

Unfortunately, knowledge of the biosorption mechanism is not easily obtained since we are not dealing with simple, clearly defined chemical compounds. Biosorbents comprise different types of cells with a highly complex structure whose various building blocks consist of a multitude of different molecules which in turn can display several binding sites [Naja \& Volesky, 2011]. Numerous chemical groups have been proposed to contribute to biosorption metal binding by e.g. algae, bacteria or biopolymers, including hydroxyl, carbonyl, carboxyl, sulfhydryl, thioether, sulfonate, amine, imine, amide, imidazole, phosphonate, phosphodiester groups. In another hand biosorption depends on factors as: quantity of sites in the biosorbent material, accessibility of the sites, chemical state of the site and affinity between site and metal [Naja \& Volesky, 2011]. Competition will also occur between cations and such an effect can also depress biosorption of the metal of interest. Various selectivity series have been published which reflect such competition, e.g. $\mathrm{Cu}^{2+}>\mathrm{Cd}^{2+}>\mathrm{Ni}^{2+}>\mathrm{Pb}^{2+}>\mathrm{Zn}^{2+}, \mathrm{Co}^{2+}>\mathrm{Cr}^{3+}$ for Chlorella vulgaris, and $\mathrm{Cu}^{2+}>\mathrm{Sr}^{2+}>\mathrm{Zn}^{2+}>\mathrm{Mg}^{2+}>\mathrm{Na}^{+}$for Vaucheria sp.[Gadd, 2009]. In some cases, cations may increase biosorption of anionic species by enhancing binding of the negativelycharged anions. In some cases, cation loading of biomass may enhance biosorption of another cation because of $\mathrm{pH}$ buffering effects[Gadd, 2009].

\section{Biosorption of copper ion by Sahara plants}

Conventional wastewater treatment including sludge separation, chemical precipitation, electrochemical process, membrane separation, reverse osmotic treatment, ion-exchange and solvent extraction are often expensive, require high energy, have low selectivity and are impractical when they are used to treat the wastewaters with heavy metal ions amount lower than $100 \mathrm{mg} \mathrm{l}^{-1}$ [ Cheriti et al, 2009; Talhi et al, 2010]. 
Screening of vegetable biomass types for heavy metals biosorption constitutes an important way of identifying the most promising types of biomass. Considerable efforts go into testing many different materials in order to assess their metal-sorbing potential. This is done mainly based on simple batch equilibrium sorption tests [Naja \& Volesky, 2011]. Thus, several approaches have been studied and developed for the effective removal of heavy metals using biosorbents like peat, fly ash, algae, soya bean, hulls leaf mould, sea weeds, coconut husk, sago waste, peanut hull, hazelnut, bagasse, rice hull, sugar beet pulp, plants biomass and bituminous coal. It has also been observed that these biosorbents need further modifications to increase the active binding sites and also made them readily available for sorption [Talhi et al, 2010]

In the program of the valorization of Algerian Sahara plants initiated by our laboratory, we attempt to use some Saharan plants as low-cost biomaterials for the biosorption of toxic heavy metals from water and a suitable for application in small industries and for sustainable development. So, the objective of our studies was to utilize the locally available plants: Acacia raddiana, Anabasis aretioides, Retama raetam and Tamarix gallica as an adsorbent for removal of copper ion from aqueous solution. Effects of operating conditions like initial metal concentration, $\mathrm{pH}$ and temperature, on copper biosorption were investigated. The relation between the phytochemical composition and the percent of adsorption for copper ion was examined.

\subsection{Materials and methods}

\subsubsection{Biosorbent preparation}

All plants were collected from their natural habitat in El Bayadh region (south Algeria) for Retama raetam and from Saoura desert (south Algeria) for Acacia raddiana, Anabasis aretioides, and Tamarix gallica. We used the bark of tree Acacia raddiana and Tamarix gallica and the aerial parts of Anabasis aretioides and Retama raetam. The biomass was washed with distilled water several times to remove soil-associated particles and water soluble materials. The dried biomass, ground in a mortar to powder and sieved into a size ranging from 125 to $250 \mu \mathrm{m}$, was stored in a desiccator until use for the biosorption process.

\subsubsection{Biosorption studies}

All chemicals used in this study were of analytical grade and solutions were prepared using double distilled water. $\mathrm{Cu}^{2+}$ solution was prepared by dissolving copper sulfate in distilled water. Hydrochloric acid and sodium hydroxide solutions were used to adjust the solution $\mathrm{pH}$. The $\mathrm{pH}$ was measured using Hanna $\mathrm{pH}$ meter at the beginning and at the end of the experiments.

Batch experiments were carried out by shaking $100 \mathrm{mg}$ of biosorbent mixed with $100 \mathrm{ml}$ of copper sulfate solution of known concentration in $200 \mathrm{ml}$ Erlenmeyer flasks stirred at constant speed in a magnetic shaker in a thermostatic bath. After, the solid was removed by filtration through a filter paper (Whatman GF/A). Blank runs, with only the sorbent in 100mL of double distilled water, were conducted at similar conditions. The equilibrium metal concentration in the filtrates as well as in the initial solution was analyzed using atomic adsorption spectrophotometer (Perkin Elmer Analyst 700). Each experiment was carried out in duplicate.

\subsection{Quantifying copper metal-biomass interactions}

The identification of the physico-chemical interactions between active sites on the adsorbent and metallic species, and the quantification of metal removed according to different mechanisms (physical adsorption, ion exchange, complexation, chelation, surface 
microprecipitation) is an intriguing target that would allow the precise description of the effect of the environmental factors. Than, the biosrption capacity is governed by a series of properties, such as pore and particle size distribution, specific surface area, cation exchange capacity, pH, surface functional groups, and temperature [Naja \& Volesky, 2011].

\subsubsection{Effect of initial copper ions concentration}

According to our recent works [ Cheriti et al, 2009; Talhi et al, 2010], we have determined the optimum time of biosorption for different initial concentrations (varied between 50 and $300 \mathrm{mg} \mathrm{l}^{-1}$ ). Than, biosorbed copper ion concentrations increased with time and reached equilibrium after $04 \mathrm{~h}$ for all initial copper ion concentrations tested, an increase of removal time to $24 \mathrm{~h}$ does not show notable effects.

An important parameters in biosorption of heavy metal ions is the equilibrium solid phase metal ion concentration. We noted that $\mathrm{q}_{\mathrm{e}}$, the $\mathrm{Cu}^{2+}$ equilibrium concentration in solid phase $\left(\mathrm{mg} \mathrm{Cu} \mathrm{g}\right.$ biomass $\left.{ }^{-1}\right)$, increased rising initial $\mathrm{Cu}^{2+}$ concentration . In the case of Acacia raddiana, Copper ion percent removal decreased from $94 \%$ to $39 \%$ (Fig. 2) and the final $\mathrm{Cu}^{2+}$ concentration increased from $3 \mathrm{mg} \mathrm{l}^{-1}$ to $183 \mathrm{mg} \mathrm{l}^{-1}$ (Fig. 3) when the initial $\mathrm{Cu}^{2+}$ concentration was raised from $50 \mathrm{mg} \mathrm{l}^{-1}$ to $300 \mathrm{mg} \mathrm{l}^{-1}$ at constant $\mathrm{pH}$ 5.0. At low initial $\mathrm{Cu}^{2+}$ concentrations, such as $50 \mathrm{mg} \mathrm{l}^{-1}$ and $100 \mathrm{mg} \mathrm{l}^{-1}$, all copper ions were biosorbed onto binding sites on Acacia raddiana bark surfaces.

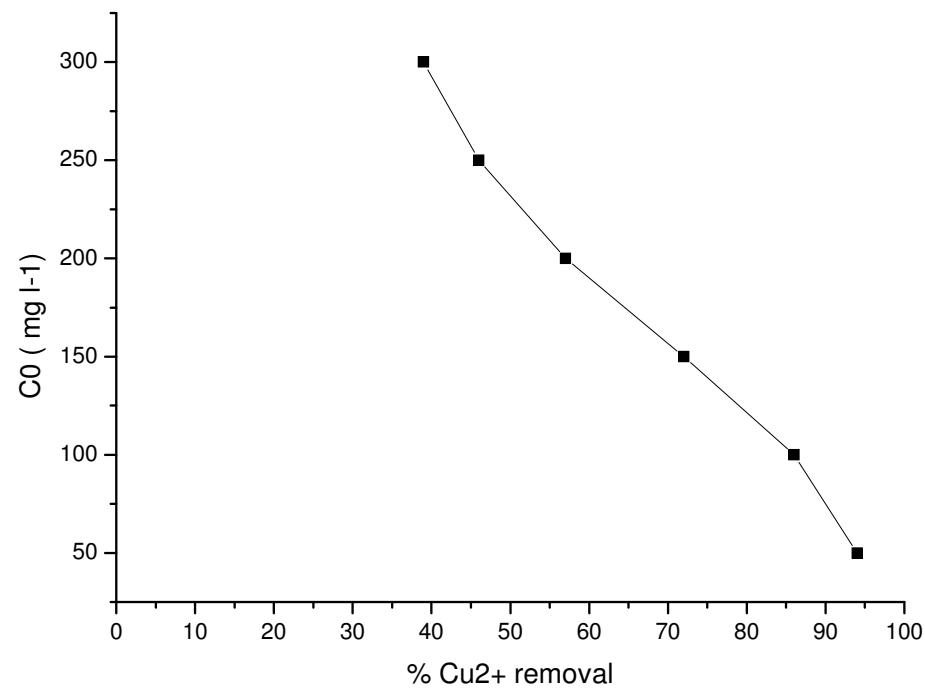

Fig. 2. Variation of percent copper removal with the initial copper ion concentration at the end of $4 \mathrm{~h}, \mathrm{pH} 5, \mathrm{~T}=25 \pm 0.1^{\circ} \mathrm{C}$ for Acacia raddiana

For Retama reatem, at $\mathrm{pH} 5$. the percent copper ion removal decreased from $88 \%$ to $38 \%$ and the final $\mathrm{Cu}^{2+}$ concentration increased from $6 \mathrm{mg} \mathrm{l}^{-1}$ to $186 \mathrm{mg} \mathrm{l}^{-1}$ when the initial $\mathrm{Cu}^{2+}$ concentration was raised from $50 \mathrm{mg} \mathrm{l}^{-1}$ to $300 \mathrm{mg} \mathrm{l}^{-1}$. At low initial $\mathrm{Cu}^{2+}$ concentrations, such as $50 \mathrm{mg} \mathrm{l}^{-1}$ and $100 \mathrm{mg} \mathrm{l}^{-1}$ ( Fig. 4), all copper ions were biosorbed onto binding sites on $R$. raetam plant surfaces. However, at high initial copper ion concentrations, such as $250 \mathrm{mg} \mathrm{l}^{-1}$ and $300 \mathrm{mg} \mathrm{l}^{-1}$, a large fraction of binding sites on biomass surfaces were occupied by copper ions. 


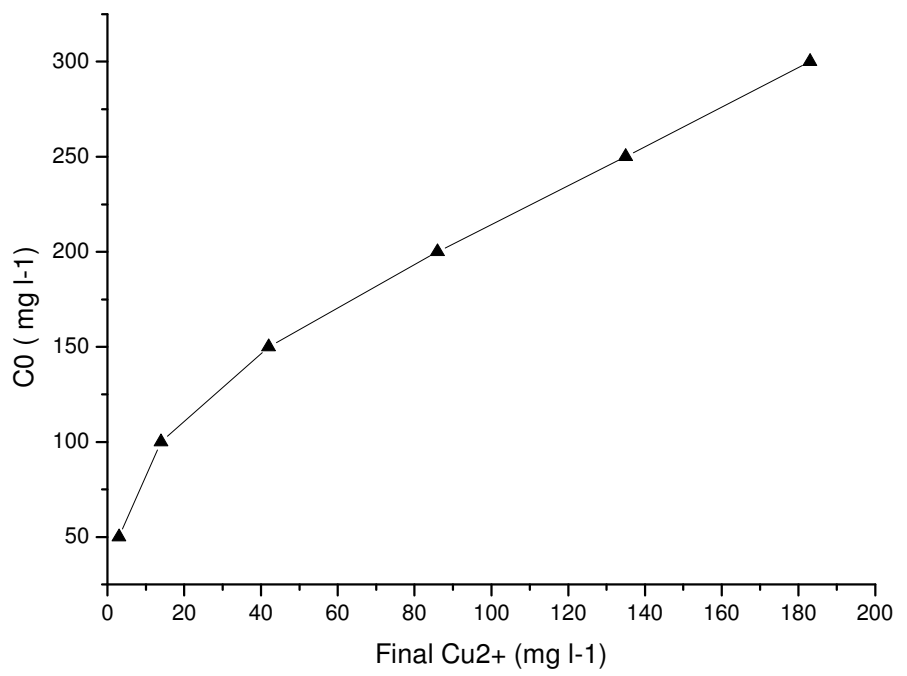

Fig. 3. Variation of final $\mathrm{Cu}^{2+}$ concentration with the initial copper ion concentration at the end of $4 \mathrm{~h}, \mathrm{pH} 5, \mathrm{~T}=25 \pm 0.1^{\circ} \mathrm{C}-$ Acacia raddiana

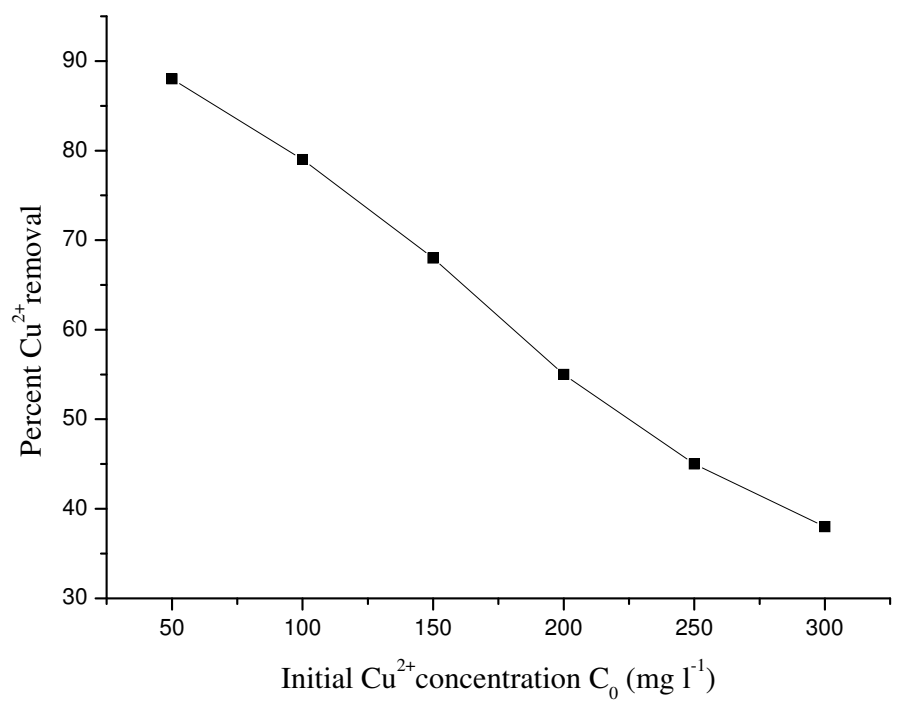

Fig. 4. Effects of initial copper ion concentration on the percent $\mathrm{Cu}^{2+}$ removal by Retama raetam plant

\subsubsection{Effect of $\mathrm{pH}$}

The $\mathrm{pH}$ of the solution is the most important parameter that in the biosorption process can significantly influence the removal of heavy metals. The effect of $\mathrm{pH}$ on the sorption of copper (II) have been studied using different sorbent types and optimum sorption capacities have been reported at $\mathrm{pH}$ values of 5, 6 and 7 [Cheriti et al, 2009; Talhi et al 2010]. 
Keeping the same experiment conditions with $100 \mathrm{mg} / \mathrm{L}$ of copper ions solution as mentioned previously (times $=04 \mathrm{~h}, \mathrm{~T}=25^{\circ} \mathrm{C}$ ), $\mathrm{pH}$ of solution was varied from 3 to 7

Data on variations of percent copper removal and biosorbed copper concentration by the four saharan plants used under different $\mathrm{pH}$ values were summarizes in Table 4

\begin{tabular}{|c|c|c|c|c|}
\hline \multirow{2}{*}{$\mathrm{pH}$} & \multicolumn{4}{|c|}{ Percent $\mathrm{Cu}^{2+}$ removal } \\
\cline { 2 - 5 } & Acacia raddiana & Retama raetem & Anabasis aretioides & Tamarix gallica \\
\hline 3 & 11 & 09 & 05 & 10 \\
4 & 64 & 58 & 14 & 58 \\
5 & 86 & 79 & 35 & 81 \\
6 & 85 & 70 & 33 & 76 \\
7 & 83 & 67 & 25 & 71 \\
\hline
\end{tabular}

Table 4. Effects of $\mathrm{pH}$ on percent copper removal and biosorbed copper concentration. Initial $\mathrm{Cu}^{2+}$ concentration $\mathrm{C}_{0}=100 \mathrm{mg} \mathrm{l}^{-1}, \mathrm{~T}=25^{\circ} \mathrm{C}, 04 \mathrm{~h}$

The greatest increase in the biosorption rate of $\mathrm{Cu}^{2+}$ ions on the plant biomass was observed at $\mathrm{pH}$ 5. At lower $\mathrm{pH}, \mathrm{H}^{+}$ions compete with copper cation for the exchange sites in the system. The heavy metal cations are completely released under circumstances of extreme acidic conditions. At $\mathrm{pH}(3-7)$ there are three species present in solution, $\mathrm{Cu}^{2+}, \mathrm{CuOH}^{+}$and $\mathrm{Cu}(\mathrm{OH})_{2}$. These species are adsorbed an electrostatically interaction at the surface of the biomass. As the $\mathrm{pH}$ decrease, the surface of the $A$. raddiana, T. gallica and $R$. raetam plants exhibits an increasing positive characteristic. $\mathrm{H}^{+}$ions present at a higher concentration in the reaction mixture and compete with $\mathrm{Cu}^{2+}$ ions for the biosorption sites resulting in the reduced uptake of Copper cation. At higher $\mathrm{pH}$ values, precipitation of $\mathrm{Cu}(\mathrm{OH})_{2}$ occurred and both sorption and precipitation would be the effective mechanisms to remove the copper ions in aqueous solution. At around $\mathrm{pH} 5$, copper cations, mainly $\mathrm{Cu}^{2+}$, would be expected to interact more strongly with the negatively charged binding sites in the sorbent. We obtained poor biosorption for the Anabasis aretiode, we think its due to the site saturation in this plants due to its ecological grows.

\subsubsection{Effect of temperature solution}

According to our previous sutdies on desert plant [Cheriti et al, 2009], we have found the same effect of the temperature on the biosorption of Copper cation. The sorption of copper cations increased slightly with the increase in temperature up to $50^{\circ} \mathrm{C}$ and then started decreasing. The temperature higher than $50^{\circ} \mathrm{C}$ caused a change in the texture of the biomass and thus reduced its sorption capacity (Table 5). Usually the physical sorption reaction is exothermic and preferred at lower temperature.

\begin{tabular}{|c|c|c|c|c|}
\hline \multirow{2}{*}{$\mathrm{T}^{\circ} \mathrm{C}$} & \multicolumn{4}{|c|}{ Percent $\mathrm{Cu}^{2+}$ removal } \\
\cline { 2 - 5 } & Acacia raddiana & Retama raetem & Anabasis aretioides & Tamarix gallica \\
\hline 25 & 86 & 79 & 35 & 81 \\
30 & 84 & 79 & 30 & 72 \\
40 & 75 & 61 & 23 & 49 \\
50 & 49 & 42 & 11 & 30 \\
60 & 36 & 21 & 11 & 89 \\
\hline
\end{tabular}

Table 5. The biosorption quantity of $\mathrm{Cu}^{2+}$ at different temperature. Initial $\mathrm{Cu}^{2+}$ concentration $\mathrm{C}_{0}=100 \mathrm{mg} \mathrm{l}^{-1}, \mathrm{pH} 5,04 \mathrm{~h}$ 
For the excellent source of biosorbent Acacia raddiana, we have determined the biosorption isotherms. Than, the isotherms were found to be linear over the entire concentration range studied with a good linear regression coefficient for Langmuir and Freundlich models respectively $\left(R^{2}=0.985\right)$ and $\left(R^{2}=0.917\right)$. The parameters of both models determined by least squares fit of the experimental biosorption data are presented in Table 6.

\begin{tabular}{|ccc|ccc|}
\hline \multicolumn{3}{|c|}{ Langmuir } & \multicolumn{3}{c|}{ Freundlich } \\
\hline $\mathrm{q}_{\mathrm{m}}(\mathrm{mg} / \mathrm{g})$ & $\mathrm{b}$ & $\mathrm{R}^{2}$ & $\mathrm{~K}_{\mathrm{F}}$ & $\mathrm{n}$ & $\mathrm{R}^{2}$ \\
82.63 & 0.073 & 0.985 & 8.75 & 1.54 & 0.917 \\
\hline
\end{tabular}

Table 6. Parameters of the Langmuir and Freundlich isotherms for the biosorption of Copper ions onto Acacia raddiana bark

Fig. 5 shows the comparison of the experimental equilibrium data and the theoretical isotherm predicted by the Langmuir and Freundlich models. It was observed that Langmuir acceptably fit the experimental results with an acceptable coefficient. The maximum sorption capacity $q_{\mathrm{m}}$ of the Acacia raddiana bark was $82.63 \mathrm{mg} / \mathrm{g}$ which indicates that this biosobent is a quite good and attractive in treatment of diluted ions copper solutions.

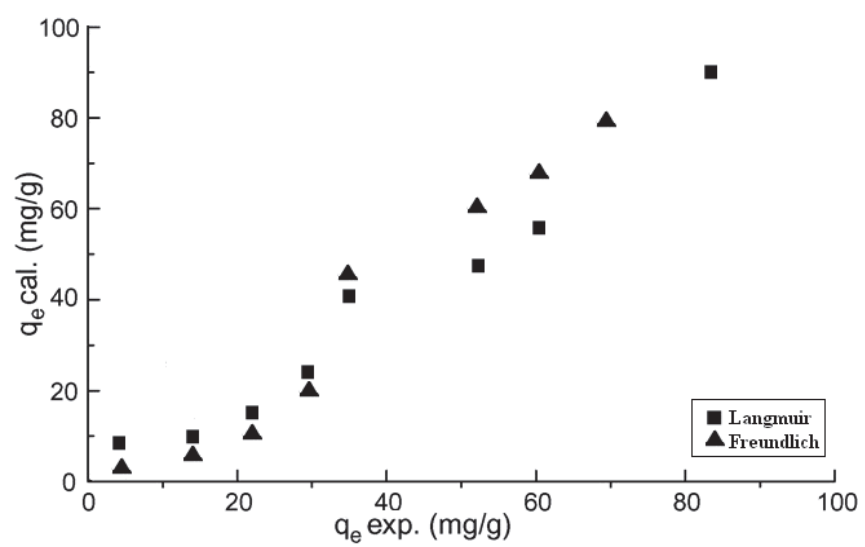

Fig. 5. Comparison of Langmuir and Freundlich models with experiment data of copper sorption by Acacia raddiana bark

\subsection{Relation biosorption - phytochemical composition}

Acording to our previous phytochemical screening of the Saharan plants, we reported the presence an important quantities in all plants of Flavonoids, Tritepenoids saponin, Alkaloids, Phytosterol, Cellulose, Hemicellulose and Lignin. Thus the substances detected are known to contain the functions (hydroxyl $\mathrm{OH}$, carboxyl $\mathrm{COOH}$, in Flavonoids, Tritepenoids saponin, Phytosterol, Cellulose, Hemicellulose, Lignin and amine function NHR, NR 2 in Alkaloids). It has been reported that the Acacia raddiana, Retama reatem and Tamarix gallica contain various polyphenols compunds and are rich on flavones and glycosides flavonoids [Cheriti, 2000; Cheriti et al, 2004; Cheriti et al, 2006 ]. It's known that these natural compounds present in the cell wall are the most important sorption sites. Therefore, the important of these natural compounds is that they contain functional groups as hydroxyl, carboxylic, carbonyl and amine groups which are important sorption sites for the binding of metal ions. Thus, biosorption of 
copper ion occurs as a result of ion exchange or complex formation between metal ions and functional groups (hydroxyl, amine, carboxyl...) on the cell surface of the biomass. In another hand, all active sites involved in heavy metal biosorption can be extremely heterogeneous according to the wide variety of biosorbents used for this application. Direct comparison of the used sorbent materials is difficult, since vegetable materials applied are different. The sorption capacities of Acaciai raddiana, Tamarix gallica and Retama raetam are relatively similar

\section{Conclusion}

Biosorption is an important process in the environment, and in several conventional waste treatment processes. By using Saharn plants, biosorpion of copper ions from aqueous solution was investigated as functions of important parameters, such as contact time, concentrations of adsorbate $\left(\mathrm{Cu}^{2+}\right.$ ions), solution $\mathrm{pH}$ and temperature. The process of biosorption has nearly reached equilibrium in 04 hours and the biosorption of metals was $\mathrm{pH}$ and temperature dependent, respectively optimal $\mathrm{pH}$ was 5 and temperature was $25-30^{\circ} \mathrm{C}$. We obtained better results with Acacia raddiana bark, Retama reatam and Tamarix galliga with percent of copper cations removal for the same initial concentration $\left(100 \mathrm{mgl}^{-1}\right)$ respectively: $86 \%, 79 \%$ and $81 \%$. Therefore, the present study demonstrates the possibility of usage of inexpensive biosorbent, as suitable alternatives for the removal of copper ions from wastewater

Finally, additional work will be required in order to determine the biosorption of other heavy metals ions, and to determine the mechanism of copper sorption by these sorbents biomaterials.

\section{References}

Ahluwalia, S.S., Goyal, D., (2007). Microbial and plant derived biomass for removal of heavy metals from wastewater. Biores. Technol. 98, 2243-2257.

Aydin H., Bulut Y., Yerlikaya C. (2008), Removal of copper (II) fromaqueous solution by adsorption onto low-cost adsorbents, Journal of Environmental Management 87 37-45.

Bae W, ChenW, Mulchandani R and Mehra RK, (2000), Enhanced bioaccumulation of heavy metals by bacterial cells displaying synthetic phytochelatins. Biotechnol Bioeng 70:518-24.

Bellakhdar, J., (1997), La pharmacopée marocaine traditionnelle. Médecine arabe ancienne et savoirs populaires. IBIS Press.

Bishop PL., (2002), Pollution prevention: fundamentals and practice. Beijing Tsinghua University Press

Benaissa H., Elouchdi M.A. (2007), Removal of copper ions from aqueous solutions by dried sunflower leaves, Chemical Eng. Nad processing, 46, 614-622

Chehma A. , (2006), Catalogue des plantes spontanées du sahara septentrional algérien, Ain Mila, Ed. Dar el Houda.

Cay S., Uyanik A., Ozasik A., (2004), Single and binary component adsorption of copper(II) and cadmium(II) from aqueous solutions using tea-industry waste, Separation and Purification Technology 38 273-280.

Cheriti A. (2000), Plantes médicinales du sud ouest algérien: Ethnopharmacologie, CRSTRA, Alger

Cheriti A. Belboukhari , N. \&Hacini S., (2004) Ir. J. Pharm. Res., 3(2), 51

Cheriti A., Belboukhari N., Sekkoum K. \& Hacini S. (2006), J. Algerien des regions arides, 5, 07-10.

Cheriti A., Talhi M.F., Belboukharia N., Taleb S., Roussel C. (2009), Removal of copper from aqueous solution by Retama raetam Forssk. growing in Algerian Sahara, Desalination and Water Treatment, 10, 317-320 
Delle Site A., (2001), Factors affecting sorption of organic compounds in natural sorbent/water systemsand sorption coefficients for selected pollutants.Areview, Journal of Physical and Chemical Reference Data 30, 187-439.

Davis, T.A., Volesky, B., Mucci, A., (2003). A review of the biochemistry of heavy metal biosorption by brown algae. Water Res. 37, 4311-4330.

Demirbas A., (2008), Heavy metal adsorption onto agro-based waste materials: A review , Journal of Hazardous Materials 157 220-229

Deng L., Su Y., Su, H. Wang X., Zhu X., (2006) , Biosorption of copper (II) and lead (II) fromaqueous solutions by nonliving green algae Cladophora fascicularis: equilibrium, kinetics and environmental effects, Adsorption 12 267-277

Djeribi R., Hamdaoui O. (2008), Sorption of copper(II) from aqueous solutions by cedar sawdust and crushed brick, Desalination 225(1-3), 95-112.

Dundar M., Nuhoglu C., Nuhoglu Y., (2008), Biosorption of $\mathrm{Cu}(\mathrm{II})$ ions onto the litter of natural trembling poplar forest, Journal of Hazardous Materials 151 86-95.

Farooq U., Kozinski JA., Khan MA.,Athar M., (2010), Biosorption of heavy metal ions using wheat based biosorbents - A review of the recent literature Bioresource Technology $1015043-5053$

Febrianto J., Kosasih AN., Sunarso J., Ju YH. , Indraswati N., Ismadji S., (2009), Equilibrium and kinetic studies in adsorption of heavy metals using biosorbent: A summary of recent studies, Journal of Hazardous Materials 162, 616-645

Gadd GM., (2009), Biosorption: critical review of scientific rationale, environmental importance and significance for pollution treatment, J Chem Technol Biotechnol; 84: 13-28

Gaff R., (1992) Chitin chemistry. Macmillan, London

Hamdy, A.A., (2000). Biosorption of heavy metals by marine algae. Curr. Microbiol. 41, 232-238.

Hashem M.A. (2007), Adsorption of lead ions from aqueous solution by okra wastes, Int. J. Phys. Sci. 2178-184.

Ibn Baytar (1992), El djamia limoufradet el Adouia, Ed Dar el koutob Elmia, Beirut.

Kapoor A, Viraraghavan T. (1995), Fungi biosorption,-an alternative treatment option for heavy metal bearing wastewaters: a review. Bioresour Technol;53:195-206.

Kapoor, A., Viraraghavan, T., Cullimore, D.R., (1999). Removal of heavy metals using the fungus Aspergillus niger. Biores. Technol. 70, 95-104.

Kramer M and Meisch H-U, (1999), New metal-binding ethyldiamino and dicarboxy products from Aspergillus niger industrial wastes. Biometals 12:241-246

Kratochvil D (1997) Biosorption of heavy metals by Sargassum seaweed biomass. Ph.D. thesis, chemical engineering, McGill University, Montreal, Canada

Kurniawan T.A., Chan G.Y.S., Lo W., BabelS., (2006), Comparisons of low-cost adsorbents for treating wastewaters laden with heavy metals, Science of The Total Environment 366, 409-426.

Kvesitadze G, Khatisashvili G., , Sadunishvili T., Ramsden JJ., (2006), Biochemical Mechanisms of Detoxification in Higher Plants Basis of Phytoremediation, Springer-Verlag Berlin Heidelberg

Le Houérou, H.N. (1990), Recherches écoclimatique et biogéographique sur les zones arides de L'Afrique du Nord. CEPE/CNRS, Montpellier

Liu N, Luo SZ, Yang YY, Zhang TM, Jin JN, Liao JL. (2002), Biosorption of americium-241 by Saccharomyces cerevisiae. J Radioanal Nucl Chem ;252: 187-91.

Lodiero, P., Herrero, R., Sastre de Vicente, M.E., (2006). Thermodynamic and kinetic aspects on the biosorption of cadmium by low cost materials: a review. Environ. Chem. 3, 400-418.

Luo F., Liu Y., Li X., Xuan Z. Ma, J. (2006), Biosorption of lead ion by chemicallymodified biomass of marine brown algae Laminaria japonica, Chemosphere 64, 1122-1127. 
Naja G., Volesky B., (2011), The mechanism of metal cation biosorption, Chapitre 3,pp 19 in P. Kotrba et al. (eds.), Microbial Biosorption of Metals, Springer Science+Business Media B.V.

Naja G, Mustin C, Volesky B, Berthelin J (2008) Biosorption study in a mining wastewater reservoir., Int J Environ Poll 34:14-27

Niua CH, Volesky B and Cleiman D. (2007), Biosorption of arsenic (V) with acid-washed crab shells. Water Res 41:2473-2478

Nurchi, V.M., Villaescusa, I., (2008). Agricultural biomasses as sorbents of some trace metals. Coord. Chem. Rev. 252, 1178-1188.

Ozenda, P.,(1991), Flore et végétation du Sahara. Ed. CNRS, Paris. 662 p.

Ozturk, A., (2007). Removal of nickel from aqueous solution by the bacterium Bacillus thuringiensis. J. Hazard. Mater. 147, 518-523.

Padmavathy V., (2008), Biosorption of nickel(II) ions by baker's yeast: kinetic, thermodynamic and desorption studies, Bioresource Technology 993100 - 3109.

Pagnanelli F., ( 2011), Equilibrium, kinetic and dynamic modelling of biosorption processes, chapiter 4, p. 59 in in P. Kotrba et al. (eds.), Microbial Biosorption of Metals, Springer Science+Business Media B.V

Pagnanelli F, Esposito A, Veglio F. (2002), Multi-metallic modelling for biosorption of binary systems. Water Res;36:4095-105.

Park D., Yun Y., Jo J.H., Park J.M., (2006) , Biosorption process for treatment of electroplating wastewater containing $\mathrm{Cr}(\mathrm{VI})$ : Laboratory-Scale Feasibility Test, Industrial and Engineering Chemistry Research 45, 5059-5065.

Popuri S.R., Jammala A., Reddy, K.V.N.S. Abburi K. (2007), Biosorption of hexavalent chromium using tamarind (Tamarindus indica) fruit shell-a comparative study, Electronic Journal of Biotechnology $10,358-367$.

Quézel, P. (1965), La vegetation du Sahara, du Tchad a la Mauritanie. Fisher Verlag, Stuttgart. 333pp.

Rahman, H.U., Shakirullah, M., Ahmad, I., Shah, S., Shah, A.A., (2005). Removal of copper (II) ions from aqueous medium by sawdust of wood. J. Chem. Soc. Pak. 27, 233-238.

Shaker M.A., (2007), Thermodynamic profile of some heavy metal ions adsorption onto biomaterial surfaces, American Journal of Applied Sciences 4 605-612.

Sud, D., Mahajan, G., Kaur, M.P., (2008). Agricultural waste material as potential adsorbent for sequestering heavy metal ions from aqueous solutions - a review. Biores. Technol. 99, 6017-6027.

Talhi M.F., Cheriti A., Belboukharia N., Agha L., Roussel C. (2010), Biosorption of copper ions from aqueous solutions using the desert tree Acacia raddiana, Desalination and Water Treatment, 21 323-327

Vilar V.J.P., Botelho C.M.S., Boaventura R.A.R., (2008) Copper removal by algae Gelidium, agar extraction algal waste and granulated algal waste: kinetics and equilibrium, Bioresource Technology 99 750-762.

Wang J., Chen C. (2006), Biosorption of heavy metals by Saccharomyces cerevisiae: A review, Biotechnology Advances 24 427-451

Wang JL. (2002), Biosorption of copper (II) by chemically modified biomass of Saccharomyces cerevisiae. Process Biochem;37: 847-50.

Weppen P, Hornburg A (1995) Calorimetric studies on interactions of divalent-cations and microorganisms or microbial envelopes. Thermochim Acta 269/270:393-404

Zhang Y, Banks C, (2006), Acomparisonof theproperties of polyurethane immobilised Sphagnum moss, seaweed, sunflower waste and maize for the biosorption of $\mathrm{Cu}, \mathrm{Pb}$, Zn and Ni in continuous flow packed columns. Water Res 40:788-798. 


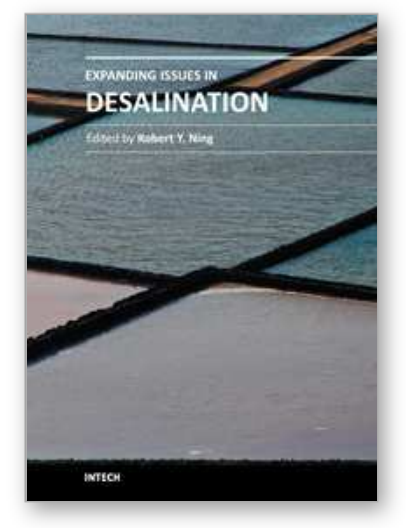

\author{
Expanding Issues in Desalination \\ Edited by Prof. Robert Y. Ning
}

ISBN 978-953-307-624-9

Hard cover, 412 pages

Publisher InTech

Published online 22, September, 2011

Published in print edition September, 2011

For this book, the term â€œdesalinationâ€ is used in the broadest sense of the removal of dissolved, suspended, visible and invisible impurities in seawater, brackish water and wastewater, to make them drinkable, or pure enough for industrial applications like in the processes for the production of steam, power, pharmaceuticals and microelectronics, or simply for discharge back into the environment. This book is a companion volume to â€œDesalination, Trends and Technologiesâ€, INTECH, 2011, expanding on the extension of seawater desalination to brackish and wastewater desalination applications, and associated technical issues. For students and workers in the field of desalination, this book provides a summary of key concepts and keywords with which detailed information may be gathered through internet search engines. Papers and reviews collected in this volume covers the spectrum of topics on the desalination of water, too broad to delve into in depth. The literature citations in these papers serve to fill in gaps in the coverage of this book. Contributions to the knowledge-base of desalination is expected to continue to grow exponentially in the coming years.

\title{
How to reference
}

In order to correctly reference this scholarly work, feel free to copy and paste the following:

Abdelkrim Cheriti, Mohamed Fouzi Talhi, Nasser Belboukhari and Safia Taleb (2011). Copper lons Biosorption Properties of Biomass Derived from Algerian Sahara Plants, Expanding Issues in Desalination, Prof. Robert Y. Ning (Ed.), ISBN: 978-953-307-624-9, InTech, Available from: http://www.intechopen.com/books/expandingissues-in-desalination/copper-ions-biosorption-properties-of-biomass-derived-from-algerian-sahara-plants

\section{INTECH}

open science | open minds

\section{InTech Europe}

University Campus STeP Ri

Slavka Krautzeka 83/A

51000 Rijeka, Croatia

Phone: +385 (51) 770447

Fax: +385 (51) 686166

www.intechopen.com

\section{InTech China}

Unit 405, Office Block, Hotel Equatorial Shanghai

No.65, Yan An Road (West), Shanghai, 200040, China 中国上海市延安西路65号上海国际贵都大饭店办公楼405单元

Phone: +86-21-62489820

Fax: +86-21-62489821 
(C) 2011 The Author(s). Licensee IntechOpen. This chapter is distributed under the terms of the Creative Commons Attribution-NonCommercialShareAlike-3.0 License, which permits use, distribution and reproduction for non-commercial purposes, provided the original is properly cited and derivative works building on this content are distributed under the same license. 